\title{
ASSOCIATION OF NOVEL POLYMORPHISM OF ESR2 GENE (G40100A) WITH PRODUCTION TRAITS OF BROWN LOCAL IRAQI CHICKEN
}
R.. I. A. Abu-Rekaiba
W. M. Razuki
E. H. AL-Anbari
Researcher
Senior Researchers Director
Assist. Prof.

Department of Animal production - College of Agricultural Engineering Sciences - University of Baghdad

rraed671@yahoo.com emanhadi1958@yahoo.com $\quad$ drwaleedrazuki@yahoo.com

\section{ABSTRACT}

The estrogen receptor 2 (ESR2) plays a crucial role in the growth and development of follicles and ovulation in chickens. The aim of this study was detect the association of estrogen receptor 2(ESR2) gene polymorphisms with the production performance of brown local Iraqi chicken. A total of 104 hens from the F4th generation of local chicken selected for high egg yield were used. The novel $\operatorname{SNP}(G 40100 A)$ transition within third prime untranslated region (3 prime UTR) of ESR2 gene. Three genotypes were found: Wild(GG), Heterozygous(GA), and Homozygous(AA) through (PCR-DAN sequencing). Chi-square analysis showed no significant in genotypic and allelic frequencies for SNP which were agreement with HardyWeinberg equilibrium. The genotypes GG and GA were significantly superior with age at sexual maturity compared to AA genotype. The genotype GA was significantly associated with hen day egg production (HDEP) at 30 weeks compared to genotype AA, as well as the genotype GA highest significant variance was reported comparing with the GG genotype in HDEP at 45 and 60 weeks, thus, the study recommends to exploit this ESR2 gene polymorphism (G40100A) as promising marker in breeding program via, the selection of individuals carrying the genotype GA, characterized by the high egg production.

Keywords: DNA Sequencing, estrogen receptor 2, genotype, breeding programs

\begin{tabular}{|c|c|c|}
\hline ابو ركيبة وآخرون & & مجلة العلوم الزراعية العراقية - 21 \\
\hline \multicolumn{3}{|c|}{ علاقة تعدد المظاهر الجديد في جين G40100A) ESR2) مع الصفات الانتاجية للاجاج العراقي المحلي البني } \\
\hline ايمان حسن هادي الانباي & وليد محمد رزوقي & رائد ابراهيم احمد ابو ركيبة \\
\hline استاذ مساعد & رئيس باحثين اقدم & باحث \\
\hline
\end{tabular}

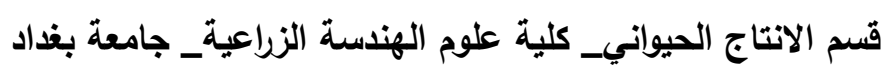

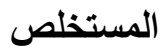

يلعب مستقبل هرمون الاستروجين 2 (ESR2) دورًا مهمًا في نمو وتطور الجريبات والإباضة في الاجاج. الهدف من هذه الدراسة هو

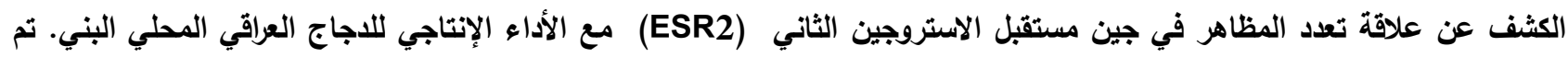

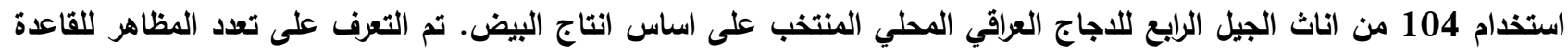

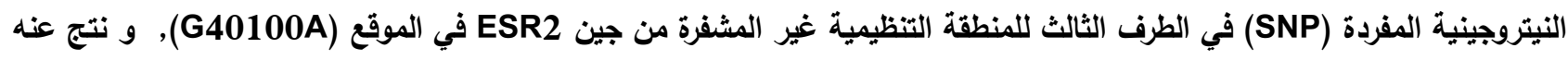
ثلاثة طرز وراثية (AA و GA , GG) من خلال تقانة تفاعل البلمرة التسلسلي و معرفة تتابع الحامض النووي للمنطقة المستهدفة (PCR-DNA sequencing)

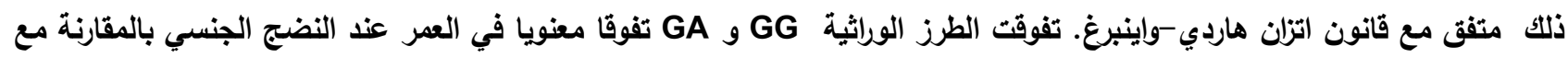

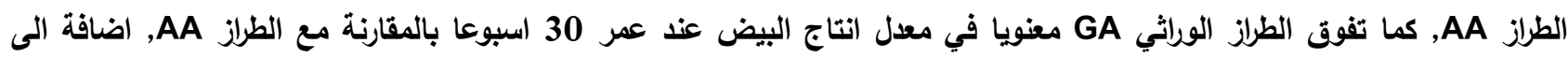

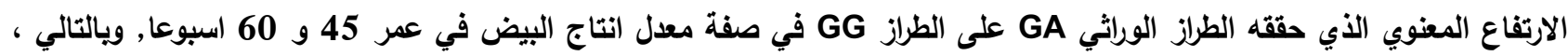

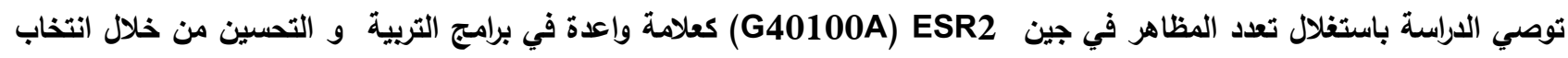

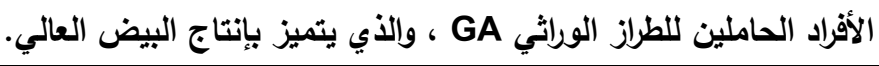
الكلمات المفتاحية: تتابع الحامض النووي, مستقبل الاستروجين الثاني, الطراز الوراثي, برامج التربية و التحسين لتراتين 


\section{INTRODUCTION}

The eggs are of the best source of protein and omega3 as food for human. The process of egg formation is a complex functional process that depends on many factors such as genetic, species, metabolism, nutrition and environment. Eggs is determined by a number of including shape, taste, color and egg weight (7). Egg production is a vital process regulated by a wide range of endocrine system pathways through a set of complex genes that control egg form, therefore, it is very difficult to obtain rapid progress using the classical methods of genetic improvement within the breed ( 8 and 18). One of the methods by which a lot of genetic improvement can be achieved is the genetic variation in the DNA sequence, specifically in the genes responsible for the quantitative traits, and the recent developments in the field of molecular technology provided new opportunities for genetic diversity evaluation at the level of DNA, which allowed the possibility of applying methods of genetic selection in the poultry industry, as progress in the field of molecular genetics of domestic animals has led to the identification of genes and signs associated with those genes that it affects the characteristics of egg production, which led to an increase in the rate of egg production(9 and 16). Estrogen receptor 2(ESR2) gene is the most important of these candidate genes as selection indication in local chicken improvement programs. (19). The chicken ESR2 gene, located on chromosome 5. It contains 41,734kelobase (kb) with eight exons encoding a 472-amino acid protein called (ER $\beta)$. It plays an important predominant role in estrogen activity within the chicken ovary (5 and 14). The DNA sequence of the ESR2 gene has an important role in the development of ovaries and egg production (4 and 25). Since there is no study about the possibility of employing this gene in the selection and improvement process of local Iraqi chicken and its close relationship with characteristics of egg production, so a very important current study was conducted, which was intended to pinpoint the relationship of the novel polymorphism in the DNA sequence of the gene, with egg productive traits and using as a genetic indicator for improving the egg production traits in the brown local Iraqi chickens.

\section{MATERIALS AND METHODS}

\section{Hens and character measurements}

This research was conducted at the poultry station in the Animal Resources Department of the Office of Agricultural Research - Ministry of Agriculture. As for laboratory work, it was in the Office of WAHJ ALDNA for chemical analysis, Baghdad -Karrada. A total of 104 hens of the F4th generation of brown local Iraqi chickens were used. The hens were kept at individual cages equipped with longitudinal feeders and water nipples. The dimension of each cage was 40 (length) 40 (width) 60 (height) $\mathrm{cm}$. The preventive and health program that recommended from the Office of Agricultural Research was recommended. Five types of feeding were used, according to age. The lighting program used was depended by the Office of Agricultural Research with a lighting power of 60 watts, with the lighting hours number $15 \mathrm{~h}$ from 15 wks of age to the end of production period(1). The mean of body weight,age at sexual maturity, the first egg weight, the egg laying clutch, hen days egg production (HDEP) and the weight of eggs produced was calculated for genotypes.

\section{DNA extraction}

At 320 days of age, three $\mathrm{ml}$ of blood were collected from individuals of the 104 local Iraqi hens under the study via the wing vein. Genomic DNA was extracted using G- spin DNA extraction kit by intron company/ Korea. Prior DNA extraction, blood volume was changed to 10 microliters (2). for guarantee genomic DNA purity, according to(20), the agarose gel has been made in $1 \%$ concentration by dissolving $1 \mathrm{~g}$ of agarose in $100 \mathrm{ml}$ of previously made TBE buffer (19). Three $\mu$ l of the processor loading dye (Intron / Korea) has been blended with $5 \mu \mathrm{l}$ of the supposed DNA to be electrophoresis, after the mixing process, the mixture is loaded at the gel holds. An electric current of 7 vlc 2 has been exposed for $1.5 \mathrm{~h}$ till the tincture has arrived to the other side of the gel. The gel has been tested by ultraviolet spectrophotometer source with $336 \mathrm{~nm}$ after putting the gel in the pool which contains $30 \mu \mathrm{l}$ Red safe nucleic acid staining solution and $500 \mathrm{ml}$ of distilled water. 


\section{Primers designation}

To find the genetic variation in the estrogen receptor 2 (ESR2) gene, primer was designed for the target gene fragment and shown in tables (1). The primers had been supplied by an integrated DNA technologies company(IDT)/Canada.

Table 1. The specific primer of ESR2 gen

\begin{tabular}{|cccrc|}
\hline Gene & Primer & Sequence & Tm $\left({ }^{\circ} \mathrm{C}\right)$ & GC $(\%)$ \\
\hline ESR2 & Forward & 5'-TCT TCC TGC TCA GCCAGT TG - 3' & $\mathbf{5 7 . 3}$ & $\mathbf{5 5}$ \\
ESR2 & Reverse & 5'-GCT CTG AAC TGG CCCAAG AT - 3' & $\mathbf{5 7 . 5}$ & $\mathbf{5 5}$ \\
\hline
\end{tabular}

\section{Polymerase chain reaction(PCR) \\ The total size of the reaction is $25 \mu 1$, PCR} PreMix $5 \mu$, DNA 1.5, forward primer $1 \mu 1$, reveres primer $1 \mu \mathrm{l}$, and $\mathrm{DdH} 2 \mathrm{O} 16.5 \mu \mathrm{l}$.The temperature has identified (Initial denaturation and annealing) after several experiments (Gradient PCR). The optimum denaturation temperatures $95^{\circ} \mathrm{C}$ and, annealing temperatures $62^{\circ} \mathrm{C}$ used to detect target regions of ESR 2 .

\section{PCR product electrophoresis}

To preparation of gel, the percentage $2 \%$ of agarose was used, by melting $2 \mathrm{~g}$ of agarose in $100 \mathrm{ml}$ of previously made TBE buffer. five $\mu l$ of the PCR product was loaded into the holes of the gel and $5 \mu \mathrm{l}$ of the ladder was loaded into the first hole of the gel. An electric current of $7 \mathrm{vlc} 2$ has been exposed for $1.5 \mathrm{~h}$ till the tincture has arrived the other side of the gel figures(1). The gel has been tested by a source of the UV with $336 \mathrm{~nm}$ after putting the gel in the pool which contained $30 \mu 1$ red safe nucleic acid staining solution and $500 \mathrm{ml}$ from distilled water. Note: Loading dye will not be added for the PCR product electrophoresis because the master mix contains a dye.

\section{DNA sequencing}

PCR product samples were sent to the biogen company in South Korea to determine the target regions sequence for each gene, by sequencer device, then detect the genotypes.

\section{Sequence results analysis}

For genotyping, the results of sequence were analyzed by(geneious prime program); it is the $\mathrm{P}+\mathrm{q}=1$ world's leading bioinformatics software platform for molecular biology and sequence analysis. Note: an analysis of the valid samples had been depended, which have high quality, according to the program. The genotypes were determined by comparing nucleotides type and number of alleles that appeared in DNA sequence for each individual with the DNA of Gallus gallus domesticus the recorded by NCBI.

Statistical analysis: Data were statistically analyzed using the Statistical Analysis System program (21) to study the relationship the ESR2 gene with egg production traits for the F4th generation of brown local Iraqi chickens according to the mathematical model shown below and calculated the significant differences between the averages using the polynomial Duncan test (6).

$Y i j=\mu+B i+e i j$

Yij: the value of observation $\mathrm{j}$ that belongs to the genotype i . $\mu$ : the average of the measured trait

$\mathrm{Bi}$ : the effect of the ESR2 gene polymorphism of the site (G40100A)

eij: random error which is distributed normally an average equal to zero and variance of $\sigma^{2} \mathrm{e}$

\section{Polymorphism evaluations}

Frequencies of genotypes and alleles at each SNP site were calculated, by Hardy-Weinberg equilibrium using (Chi-square $\chi^{2}$ ) test to compare the percentages of genotypes for each gene (degree of freedom $=1$ ).

\section{$\mathbf{P A}=$}

$$
2 * \text { No. of Homozygous }+1 * \text { No. of Heterozygous }
$$

2* Total number of sample

\section{RESULTS AND DISCUSSION}

PCR of estrogen hormone receptor 2 gene

(ESR2): A specific sequence of the estrogen receptor 2 gene was amplified using the primers, the size of amplified PCR product was found to be -1181 bp (Figure1). 


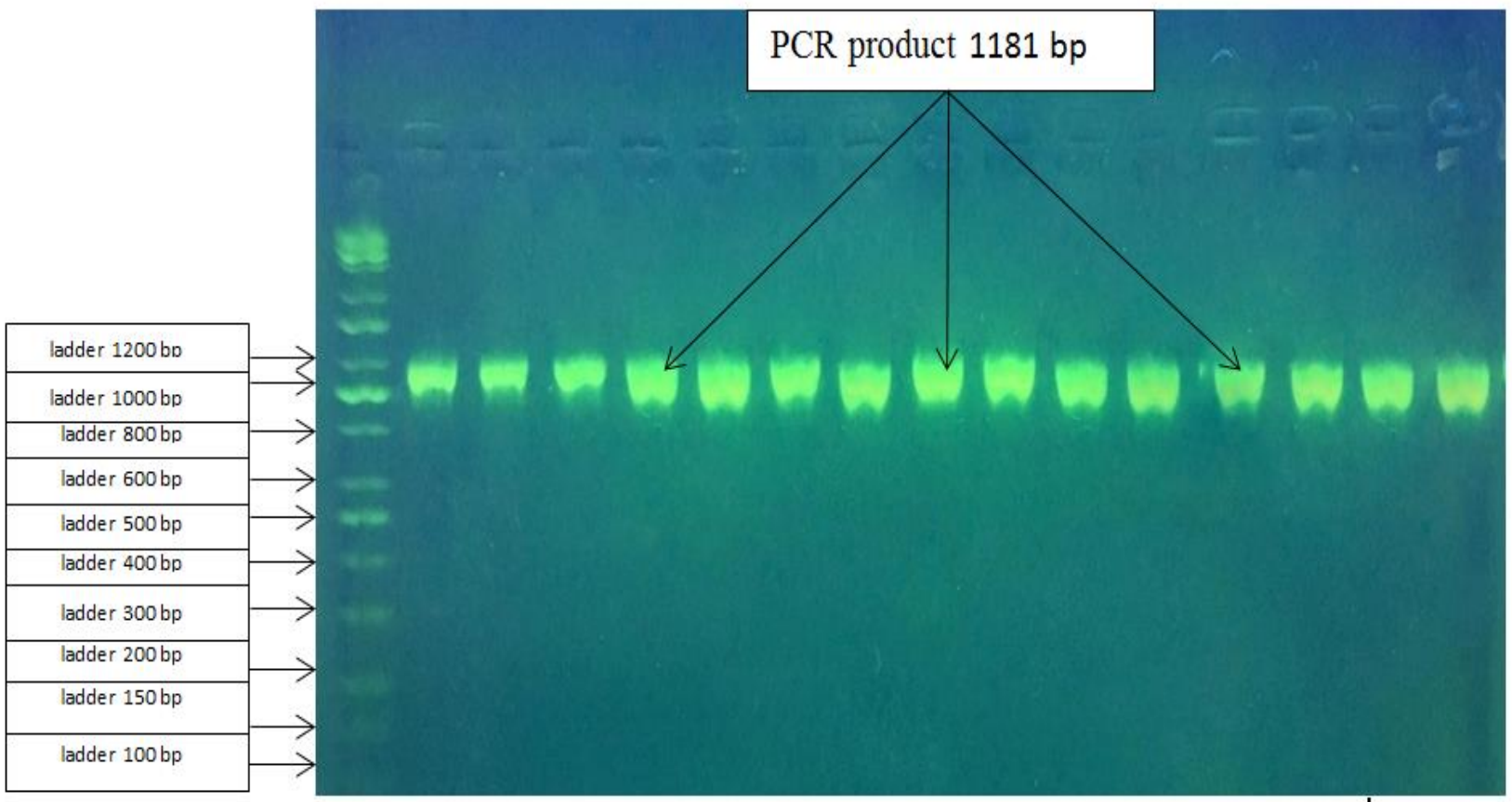

Figure 1. Electrophoresis of PCR amplified product of ESR2 gene, the product was electrophoresis on $2 \%$ agarose gel at 7 volt $/ \mathrm{cm} 2$ for 1.5 hour, PCR product $1181 \mathrm{bp}$. Ladder of DNA (100-10000) bp

Detection of polymorphism and genotypes in ESR2 gene: To find genetic variation of ESR2 gene, all of the samples of PCR products were analyzed using the DNA sequence, as already described. The novel prime untranslated region (3'-UTR) of ESR2 gene with two alleles ( $G$ and $A$ )and three genotypes were found: Wild(GG), Heterozygous(GA)and Homozygous(AA) as SNPG40100A transition located within third described in the figures 2,3 and 4 respectively.

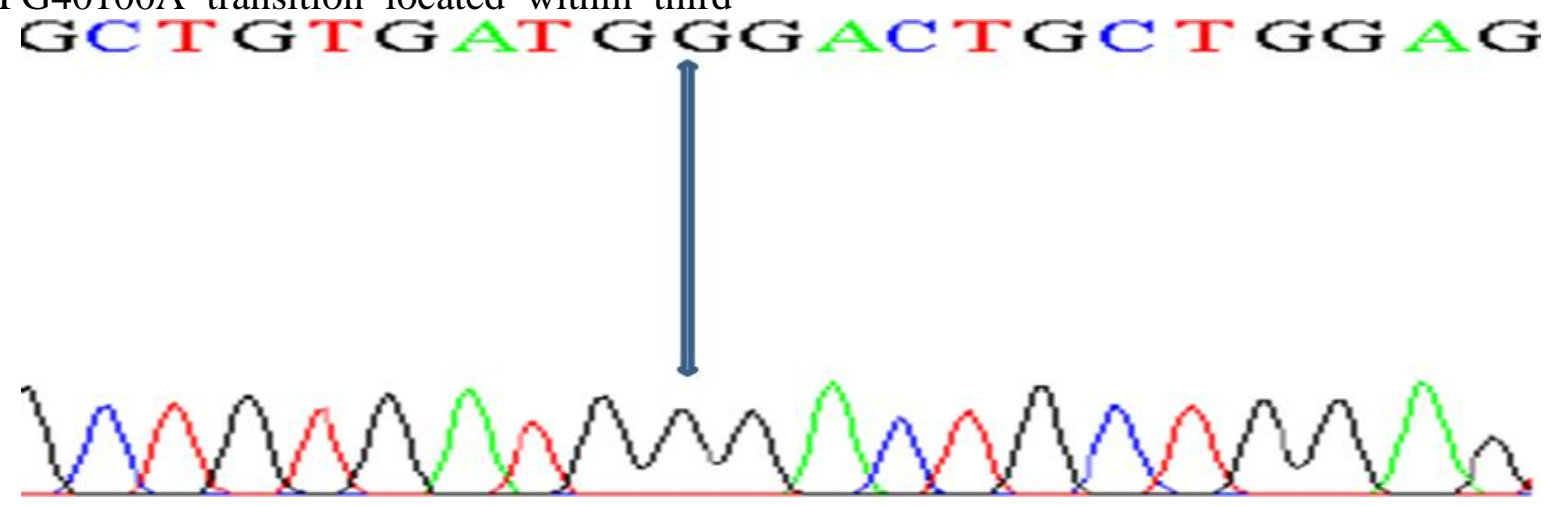

Figure 2. ESR2 gene, wild genotype (GG), one peak was evidenced within G40100A site, contains the wild allele nucleotide (G), and birds of this group were classified as wild type, with GG genotype 


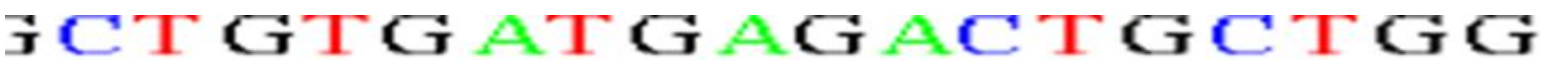

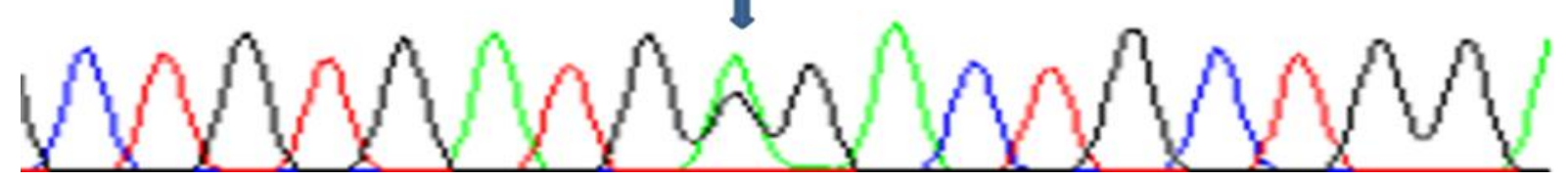

Figure 3. ESR2 gene, heterozygous genotype (GA), a transition (G40100A) in one of birds groups was found, where two peaks appeared, represent two alleles in the site of genetic variation of ESR2 (3'-UTR), one of alleles was wild (G), another to the variance allele

(A).This group is considered a heterozygous type, with GA genotype

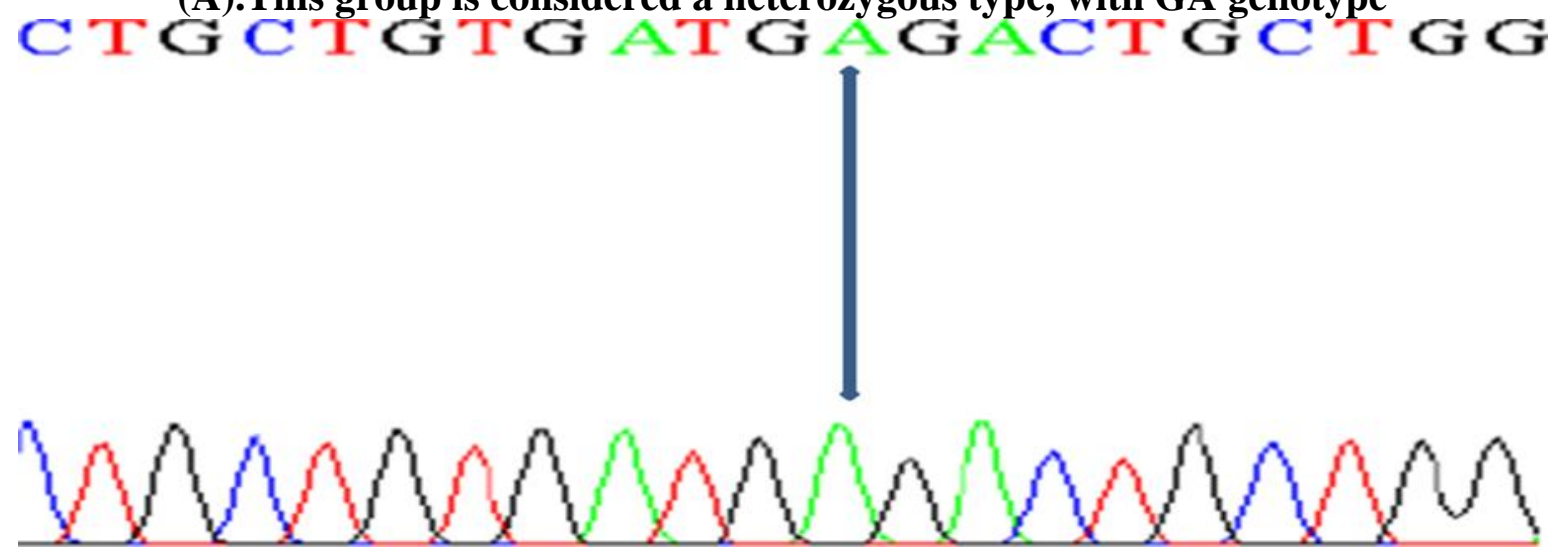

Figure 4. ESR2 gene, homozygous genotype (AA), mentions one peak with nucleotide (A). The transition (G- A) in both alleles for a site of genetic variation (G 40100A) of the ESR2 was observed. This group is classified homozygous type, with AA genotype

The above- mentioned results agreed with (12) who indicated for polymorphism in the ESR2 gene of chicken, while, it conflicted with our study regarding the location of polymorphism at gene. The difference of this study with the others is perhaps because the difference of the breeds.

Distribution of genotypes and allele frequency for $3^{\prime}$-UTR SNP (G40100A) of ESR2 gene

The results of table 2 indicate to three genotypes(GG, GA, and AA)were found of the
ESR2 G40100A in the F4th generation of brown local Iraqi chicken. The GA genotype showed the most percentage, $48.39 \%$, next GG genotype with $43.01 \%$, then AA Genotype $8.6 \%$. with 40,45 and 8 birds for each GG, GA and AA respectively. Non-significant differences showed between the percentage of these genotypes according to the Chi-square test. The allele frequency was 0.672 and 0.328 for $G$ and $A$ respectively, this result revealed that this population are agreement with HardyWeinberg equilibrium.

Table 2. Distribution of genotypes and allele frequency for 3'-UTR SNP (G40100A) of ESR2 gene

\begin{tabular}{|c|c|c|c|c|c|c|}
\hline \begin{tabular}{|c|} 
The \\
polymorphism
\end{tabular} & Genotype & $\begin{array}{l}\text { No of } \\
\text { hens }\end{array}$ & $\begin{array}{l}\text { Genotype } \\
\text { frequency }\end{array}$ & Allele & $\begin{array}{c}\text { Allele } \\
\text { frequency }\end{array}$ & $\chi^{2}$ \\
\hline & GG & 40 & $43.01 \%$ & G & 0.672 & \multirow{4}{*}{0.89} \\
\hline & GA & 45 & $48.39 \%$ & $\mathbf{A}$ & 0.328 & \\
\hline SNP G40100A & AA & 8 & $8.6 \%$ & _ & - & \\
\hline Total & 3 & 93 & $100 \%$ & - & 1 & \\
\hline P-value & & & 0.64 & & & \\
\hline
\end{tabular}


Association of ESR2 gene polymorphism in 3'-UTR (G40100A) with body weight

The table 3 was found a relationship between the polymorphism at a site G40100A of ESR2 gene specifically in 3'-UTR. The AA genotype showed a marked increase at a significant level $(p<0.05)$ in the body weight at sexual maturity (1754.29g) outperforming the GG and GA genotypes (1586.97 and 1578.71g) respectively. There are no significant differences between genotypes in the body weight of the other periods. The results are harmonious with past research of (12) who mentioned the effect of ESR2 gene polymorphism (G242A) in body weight trait, which also showed significant distinction $(\mathrm{P}<0.05)$ for genotypes containing the mutant allele (AA and GA) in the mean of body weight compared with GG genotype. Furthermore the results of this experiment were different from the prior results by (19) who referred to non-significant difference in body weight between the genotypes of the ESR2 gene of Chinese Dagu chickens. It's common that the body growth is attributed to many hormones; estrogen is one of these hormones and its level in the body (3). This means that the body weight trait is subject to the additive effect of a number of genes, therefore, the study must be depended a number of genes and their interaction effects in the quantitative traits. Researchers also indicated the role of the estrogen hormone via its receptors ER $\alpha$ and ER $\beta$ which are predominant in ovarian follicles of chicken (13 and 17). Accordingly, we believe that the polymorphism occurred in the ESR2 gene has an effect on gene expression of receptor in sexual maturity phase, then hence the hormone-binding with receptor.

Table 3. Association of ESR2 gene polymorphism in 3'-UTR (G40100A) with body weight

\begin{tabular}{|ccccr|}
\hline Body weight & & Genotypes & P- \\
& GG & GA & AA & Value \\
\hline At 17 weeks $(\mathrm{g})$ & $979.51 \pm 24.24$ & $1056.27 \pm$ & $1007.75 \pm 53.37$ & 0.08 \\
Sexual & $1586.97 \pm 28.67^{\text {b }}$ & 23.83 & & \\
maturity $(\mathrm{g})$ & & $1578.71 \pm$ & $1754.29 \pm 114.3^{\text {a }}$ & 0.05 \\
At 40 weeks (g) & $1783.19 \pm 42.99$ & $1903.56 \pm$ & & 0.2 \\
& & 48.83 & $1837.86 \pm$ & 140.75 \\
At 60 weeks $(\mathrm{g})$ & $1971 \pm 49.9$ & $2082.33 \pm$ & $2103.13 \pm$ & 0.3 \\
& & 61.67 & 122.73 & \\
\hline
\end{tabular}

Means within a row with the different superscripts are significantly different $(\mathbf{P}<0.05)$

Association of ESR2 gene polymorphism (G40100A) with age at sexual maturity, first egg weight, and egg-laying clutch

Results of the association analysis among polymorphism and age at sexual maturity (ASM), first egg weight, egg-laying clutch number (ELCN), and egg-laying clutch length (ELCL) traits are seen in table 4. The SNP G40100A genotypes GG and GA were significantly associated $(\mathrm{P}<0.0001)$ with ASM compared to AA genotype (168.73, 158.77and 202.13days) for GG, GA, and AA respectively, and with the smaller significant level $(\mathrm{P}<0.05)$ in first egg weight with improving for AA genotype contrasting to GA, without significant deferent with the GG (39.97, 38.94 and 42.67) for GG, GA, and AA respectively, in addition to the significant association $(\mathrm{P}<0.05)$ in ELCL trait at 60 weeks by recording the preference for the GA genotype over the GG, while the genotype AA did not show any significant differences with other genotypes (2.91, 3.48 and 3.1) per GG, GA, and AA genotypes respectively. However, Non-significant difference was observed between the genotypes regarding ELCL in the other weeks in addition to ELCN in all studied periods. The delayed sexual maturity may be produces eggs with higher weights (14). The high effects may be due to the SNP has been occurred in an active site of gene (10). The previous studies reported a mutation in genes where a functional single nucleotide variant in the 3'-UTR can cause increased or decreased gene expression(23). 
Table 4. Association between genotypes in ESR2 gene SNP G40100A and age at sexual maturity, first egg weight, and egg-laying clutch means

\begin{tabular}{|ccccc|}
\hline Traits & \multicolumn{3}{c}{ Genotypes } & P-Value \\
\hline ASM(day) & GG & GA & AA & 0.0001 \\
First egg weight(g) & $39.97 \pm 0.68^{\text {ab }}$ & $38.94 \pm 0.69^{\mathrm{b}}$ & $42.67 \pm 2.14^{\mathrm{a}}$ & 0.05 \\
ELCN at 30 weeks & $10 \pm 0.62$ & $10.14 \pm 0.61$ & $8.5 \pm 1.54$ & 0.6 \\
ELCL at 30 weeks & $3.68 \pm 0.23$ & $4.38 \pm 0.33$ & $3.29 \pm 1.29$ & 0.2 \\
ELCN at 45 weeks & $33.73 \pm 1.54$ & $31.18 \pm 1.29$ & $29 \pm 3.17$ & 0.28 \\
ELCL at 45 weeks & $3.39 \pm 0.2$ & $4.14 \pm 0.25$ & $3.76 \pm 0.57$ & 0.08 \\
ELCN at 60 weeks & $55.67 \pm 2.08$ & $54.49 \pm 1.89$ & $53.43 \pm 4.25$ & 0.8 \\
ELCL at 60 weeks & $2.91 \pm 0.15^{\mathrm{b}}$ & $3.48 \pm 0.18^{\mathrm{a}}$ & $3.1 \pm 0.4^{\mathrm{ab}}$ & 0.05 \\
\hline
\end{tabular}

Means within a row with the different superscripts are significantly different $(\mathrm{P}<0.05)$ : ASM= Age at sexual maturity: ELCN=Egg-laying clutch number: ELCL= Egg-laying clutch length

Association of ESR2 gene polymorphism in 3'-UTR (G40100A) with egg production and egg weight: Table 5 is annotation of the polymorphism effect in the egg production. The significant differences between the genotypes and the hen day egg production (HDEP) was showed. The SNP G40100A (ESR2) genotypes GA was significantly associated $(\mathrm{P}<0.02)$ with HDEP at 30 weeks compared to genotype AA (40.34 and 25.5 eggs) for GA and AA respectively, while GG genotype was 34.44 eggs without significant differences with other genotypes. The genotype GA highest significant variance $(\mathrm{P}<0.01)$ compared with the GG genotype in HDEP at 45 weeks (105.22 and 117.9) adding to HDEP at 60 weeks at level $(\mathrm{P}<0.01)$, as the numbers of eggs reached (156.54 and 177.27eggs) for GG and GA respectively. There are not statistically significant differences among the genotype GA and AA in HDEP at 45 and 60 weeks despite the arithmetic variances, its mentioned above that this is due to a small size of the sample in addition to the standard error height of the genotype AA. There is no significant difference between the polymorphism $\left(3^{\prime}\right.$ UTR) and means of the eggs weights in the different periods. The results of our study are consistent with (19), who mention of the association of ESR2 gene polymorphism with egg production traits in the Chinese Dagu chickens population. At the end of the study period, the great rapprochement in HDEP between genotypes GG and AA was noted, which indicated that the SNP didn't negatively effect the laying performance in a pure genotype(AA) but the hybrid genotype egg production (GA) was improved which may be directly influenced in the sexual maturity and egg laying clutch. On the other hand, the ASM delayed for the genotype AA was contributed in the egg production declined significantly at the beginning to come back to normal condition at 60 weeks of age somewhat equal with GG genotype which confirms the great role of allele $\mathrm{A}$ in a pure state by decreasing then increasing the egg production. Some researches pointed to the importance of age at sexual maturity in chickens egg production, in addition to heterosis genotype of animals that result by mating the pure parents, as the heterotic offspring traits are enhanced result of parents genetic crossing. These effects can be due to Mendelian or non-Mendelian inheritance(11). The egg production was influenced by the ESR2 gene polymorphism within (3'-UTR), which led to increase of HDEP at 30, 45, and 60 weeks of age for GA genotype, therefore, this polymorphism can be exploited to increase production. One study explained the vital role of ESR2 in the conservation of ovarian function and reproduction, and a close relationship among ESR2 and egg laying performance(23). The relationship of ESR2 gene polymorphism in 
(3-UTR) with body weight and egg production performance was observed which may be suggests to regulatory roles of untranslated regions that impacts transcription and translation processes, the previous studies are supports of the regulatory region function 3UTR that post-transcriptionally effect gene

Table 5. Association of ESR2 2 ene polymorphis and egg weight

\begin{tabular}{|lcccc|}
\hline \multicolumn{1}{|c}{ Traits } & \multicolumn{3}{c}{ The genotypes } & P-Value \\
& GG & GA & AA & \\
\hline HDEP at 30 weeks (No.) & $34.44 \pm 1.89^{\text {ab }}$ & $40.34 \pm 2.37^{\mathrm{a}}$ & $25.5 \pm 6.06^{\mathrm{b}}$ & $\mathbf{0 . 0 2}$ \\
EW at 30 weeks (g) & $45.08 \pm 0.46$ & $45.32 \pm 0.49$ & $46.76 \pm 1.07$ & 0.4 \\
HDEP at 45 weeks (No.) & $105.22 \pm 2.87^{\mathrm{b}}$ & $117.9 \pm 3.17^{\mathrm{a}}$ & $100.14 \pm 9.82^{\text {ab }}$ & 0.01 \\
EW at 45 weeks (g) & $48.71 \pm 0.44$ & $48.74 \pm 0.56$ & $51.23 \pm 1.37$ & 0.1 \\
HDEP at 60 weeks (No.) & $156.54 \pm 5.23^{\mathrm{b}}$ & $177.27 \pm 4.57^{\mathrm{a}}$ & $157.71 \pm 15.21^{\text {ab }}$ & 0.01 \\
EW at 60 weeks (g) & $50.12 \pm 0.52$ & $50.31 \pm 0.58$ & $52.06 \pm 1.43$ & 0.4 \\
\hline
\end{tabular}

Means with the different superscripts within the one-row are insignificantly different $(\mathrm{P}<0.05)$ : HDEP=Hen days egg production: $E W=$ Egg weight: $N o=$ Egg of number REFERENCES

1. Abdel Amir, M. J., W. M. Razuki., and E. H. Al-anbari. 2019. Association of polymorphisms for vasoactive intestinal peptide receptor-1 ( vipr-1 ) genes with egg prodction in local Iraqi brown chicken. Biochem. Cell. Arch. 19(1): 1319-1322

2. Al-khatib, B. G. M.2015. Effect Of Growth Hormone Gene and its Receptor Polymorphism on the Productive Performance and Some Physiological Traits of Broiler Chicken. Ph.D. Dissertation. College of Agriculture, Baghdad University

3. Badr, M. O. T., Hashem, M. A., and Gado, N. N. 2009. Effect of oestrogenic compounds on performance and biochemical parameters of chickens in Egypt, 45(3), 413-423

4. Chen, X., X .We., H. Q. Xu., Y. Zhang., J. Sun. and Z. C. Yang. 2012. Analysis on the association of intron 1 of ESR1 gene with early egg production performance in chicken. Anim. Husbandry Vet. Med. 5: 6-9 (in Chinese)

5. Drummond, A. E. and P. J. Fuller. 2010. The importance of ERbeta signalling in the ovary. J. Endocrinol. 205: 15-23

6. Duncan, D.B.1955. Multiple Rang and Multiple F-test. Biometrics.11:4- 42

7. FAO. 2013. In vivo conservation of animal genetic resources. FAO Animal Production and Health Guidelines No. 14. Rome expression, as carriers of transcription regulatory elements(22). However, there is difficulty the evaluation of genetic improvement scale, because most of the egg production characters in chicken, including: egg number, egg weight, and age of sexual maturity are inherited as polygenic traits(24). (available at http://www. fao.org/docrep/018/i3327e/i3327e00.htm)

8. Fouad, A. M., W. Chen., D. Ruan. and S. Wang. 2016. Impact of Heat Stress on Meat, Egg Quality , Immunity and Fertility in Poultry and Nutritional Factors That Overcome These Effects: International Journal of Poultry Science. 15 (3): 81-95, 2016http://doi.org/10.3923/ijps.2016.81.95

9. Fulton, J. E., M. Soller., , A. R. Lund., J. Arango. and E. Lipkin. 2012. Variation in the ovocalyxin-32 gene in commercial egg-laying chickens and its relationship with egg production and egg quality traits Variation in the ovocalyxin-32 gene in commercial egglaying chickens and its relationship with egg production and egg quality traits. Animal Jenetics. 43 (1): 102-113.

10. Gerton, J. L., S. Ohgi., M. Olsen., J. Derisi. and P. O. Brown. 1998. Effects of Mutations in Residues near the Active Site of Human Immunodeficiency Virus Type 1 Integrase on Specific Enzyme-Substrate Interactions. American Society for Microbiology. 72(6), 5046-5055

11. Gerzilov, V., V. Boncheva., and P. Petrov. 2018. Egg production from dual purpose hen genotypes reared in a free range system. Bulgarian Journal of Agricultural Science. 24(1): 119-125 
12. Hong Li., G. Zhenzhen., Y. Liyu., T. Yadong., K. Xiangtao. and L. Xiaojun. 2018. Transcriptome Profile Analysis Reveals an Estrogen Induced LncRNA Associated with Lipid Metabolism and Carcass Traits in Chickens (Gallus Gallus). Cellular Physiology and Biochemistry.50:1638-1658

13. Hrabia, A. 2014. Expression of alpha and beta estrogen receptors in the chicken ovary . Folia biologica . 56(3-4): 187-191

14. International Chicken Genome Sequencing Consortium 2004. Sequence and comparative analysis of the chicken genome provide unique perspectives on vertebrate evolution. Nature 432: 695-716.

15. International Poultry Production and Team. 2013 . Lighting program as a tool to manage sexual maturity and egg size. (n.d.), 27(3), 27

16. Janni, K. and E. Cortus. 2019. Common Animal Production Systems and Manure Storage Methods. Department of Bioproducts and Biosystems Engineering, University of Minnesota. Special Publication 67

17. Liu, L., D. Li., E. R. Gilbert., Q. Xiao., X. Zhao. and Y. Wang. 2015. Effect of Monochromatic Light on Expression of Estrogen Receptor ( ER ) and Progesterone Receptor ( PR ) in Ovarian Follicles of Chicken.Journal.Pone.10:(12)1-14. http://doi.org/10.1371/journal.pone.0144102 18. Mishra, B., N. Sah. and S. Wasti. 2019. Genetic and Hormonal Regulation of Egg Formation in the Oviduct of Laying Hens. IntechOpen. Chapter.1-10
19. Niu, X., T. L. Tyasi, N. Qin., D. Liu., H. Zhu., X. Chen., and R. X. 2017. Sequence variations in estrogen receptor 1 and 2 genes and their association with egg production traits in Chinese Dagu chickens. Journal. Veterinary. Medical. Science. 79(5):927-934

20. Sambrook, J., E.F. Fritschi. and T. Maniatis. 1989. Molecular cloning: a laboratory manual, Cold Spring Harbor Laboratory Press, New York.

21. SAS 2012. Statistical Analysis System, User's Guide. Statistical. Version $9.1^{\text {th }}$ ed. SAS. Institute Incorporated Cary. N.C. USA 22. Steri, M., Idda, M. L., Biofisica, I., M. B. Whaalen and V. Orru. 2018. Genetic Variants in mRNA Untranslated Regions. Genetic.9(4):1-36.

http://doi.org/10.1002/wrna.1474

23. Tyra, M., K. Ropka-molik., K. Pi., M. Oczkowicz and M. Szyndler-n. 2019. Association of Ghrelin Gene Polymorphisms. Animals. 9: 410

24. Venturini, G. C., R. P. Savegnago., B. N. Nunes., M. C. Ledur., G. S. Schmidt., L. El Faro. and D. P. Munari. 2013. Genetic parameters and principal component analysis for egg production from White Leghorn hens. Poultry Science. 92:2283-2289

25. Wu, Y., H. W. Xiao., Z. H. Liang., A. L. Pan., J. Shen., J. S. Pi. and Z. H. Chen. 2014. Differential expression profiling of estrogen receptor in the ovaries of two egg duck ( Anas platyrhynchos ) breeds. J. Anim. Sci., 59, 2014 (5): 238-243 